\title{
Mediation of Partial Resistance to Rice Blast Through Anaerobic Induction of Ethylene
}

\author{
Manjul P. Singh, Fleet N. Lee, Paul A. Counce, and Julia H. Gibbons
}

University of Arkansas, Rice Research and Extension Center, Stuttgart 72160.

Accepted for publication 5 March 2004.

\begin{abstract}
Singh, M. P., Lee, F. N., Counce, P. A., and Gibbons, J. H. 2004. Mediation of partial resistance to rice blast through anaerobic induction of ethylene. Phytopathology 94:819-825.

The correlation between anaerobic soil conditions and increased resistance to rice blast disease has long been observed without benefit of an adequate explanation. We researched flood depth, dissolved oxygen (DO), and ethylene relative to expression of partial blast resistance in cvs. M201, Newbonnet, LaGrue, Mars, and Cypress. Cultivar blast index (BI) and flood DO decreased with increasing flood depth. BIs were positively

$0.25 \mathrm{mM}$ ethephon, which releases ethylene, lowered BIs of Newbonnet, LaGrue, and Cypress growing upland when applied drench, foliar, or foliar-drench. If flooded, BIs of ethephon-treated cultivars were decreased by drench and foliar-drench applications only. BIs of upland plants were unchanged, whereas BIs of analogous flooded plants increased following treatment with $0.31 \mathrm{mM}$ aminoethoxyvinylglycine (AVG), an ethylene biosynthesis inhibitor. We hypothesize that varying anaerobic conditions mediate production of phytohormones, particularly ethylene, which modify expression of inherent partial blast resistance in these rice cultivars.
\end{abstract} correlated with DO. Total leaf blast lesions were 3.4 and 3.2 times greater in cvs. M-201 and LaGrue growing in a 5.0- $\mu 1 \operatorname{liter}^{-1}$ DO nutrient solution than when growing in a $0.1-\mu l$ liter $^{-1} \mathrm{DO}$ solution. Treatment with
Additional keywords: field resistance, hormone, host-pathogen interaction, Magnaporthe grisea, Oryza sativa.
Rice blast disease, incited by the fungus Magnaporthe grisea (Hebert) Barr (Pyricularia grisea Sacc. = Pyricularia oryzae Cavara), often causes epidemic yield loss in rice (Oryza sativa L.) growing in upland and shallow or intermittent flood-irrigated agronomic systems $(7,19,28,37,47)$. Rice blast control strategies include use of resistant cultivars, proper cultural practices, and timely fungicide applications. The most widespread control strategy has emphasized using race-specific major resistance genes to breed resistant cultivars and has frequently led to boom and bust cycles due to pathogen adaptation $(6,33,37)$. Alternative breeding strategies include pyramiding major resistance genes, constructing multiline resistance gene cultivars, developing cultivars with a more durable blast resistance through the lineage exclusion technique, or through use of partial (rate reducing, field or quantitative) resistance $(18,29,33,43,52)$. Resistant cultivars using lineage exclusion or partial resistance offer a more stable control option but are difficult to develop due to the complex and poorly understood nature of plant resistance mechanisms and pathogen dynamics.

Rice growers and researchers have long speculated about the nature of partial blast resistance, particularly that observed with rice growing in anaerobic conditions such as moisture-saturated soils or flooded paddies. Rice plants, which were blast-susceptible when growing upland, became moderately resistant in moist soil and resistant in flooded soil $(21,27,30)$. Upland conditions, and particularly drought stress, increase lesion number, lesion size, and severity of rice blast in susceptible cultivars $(8,14,15$, 43), whereas flood conditions reduce the number of successful blast infections, rate of lesion expansion, and disease devel-

Corresponding author: F. N. Lee; E-mail address: fnlee@uark.edu

Publication no. P-2004-0524-01R

This article is in the public domain and not copyrightable. It may be freely reprinted with customary crediting of the source. The American Phytopathological Society, 2004. opment $(23,24,27)$. Flood-induced field resistance is inherent to most rice cultivars $(7,30,45)$. Although extensively researched, questions remain concerning the nature of partial blast resistance, which is nonspecific and appears associated with physiological responses of the plant rather than variation in canopy microclimate or pathogen dynamics $(7,23,25)$.

Rice, a semi-aquatic plant, adapts to anaerobic conditions through formation of aerenchyma tissue that facilitates aeration of submerged organs (22). Rice can maintain root respiration under anaerobic conditions although root growth is reduced and root systems are shallow relative to those developed under aerobic conditions $(9,31,49)$.

Changes in soil aeration have profound effects on soil nutritional characteristics, many of which have been directly linked with blast severity, e.g., reduction of $\mathrm{Fe}^{+3}, \mathrm{Mn}^{+4}$, and $\mathrm{SO}_{4}{ }^{2}$ $(37,50)$. Anaerobic conditions develop within a few hours of flooding as dissolved oxygen (DO) in the soil solution is depleted more quickly by plant, chemical, and microbial consumption than replenished by atmospheric oxygen diffusion into saturated soil $(16,38,46)$. Nitrogen, primary among the plant nutrients known to modify rice blast severity, is radically impacted by flooding. The nitrate ion, the primary nitrogen source available to rice growing upland, increases susceptibility to rice blast disease. The ammonium ion, the primary nitrogen source under flood conditions, does not alter susceptibility or blast severity $(36,38)$. In the soil, anaerobic decomposition of organic matter initially results in accumulation of $\mathrm{H}_{2}, \mathrm{CO}_{2}$, a range of low molecular weight hydrocarbons such as methane, ethane, propane, isobutene, ethylene, propylene, and multiple fatty acids including propionic, butyric, lactic, valeric, fumaric, and succinic acids $(41,44,50)$.

Changes in soil aeration also profoundly affect hormonal balances in rice. Low oxygen in submerged tissue induces ethylene synthesis in rice $(3,10,35,42,51)$. Due to its low diffusion rate into water, ethylene is physically trapped in the rhizosphere. Increasing ambient concentrations promote additional plant ethylene biosynthesis through positive feedback $(39,40)$. Ethylene concen- 
tration increased from 0.02 to $1.0 \mu$ liter $^{-1}$ inside submerged rice internodes (35). Rice cultivars differ in ethylene production and stem elongation during submersion (51).

Although well known for inducing necrosis, ripening, chlorosis, and senescence in plants $(1,34)$, ethylene is an important putative hormonal signal in abiotic stress situations (drought, flood, senescence, wounding, nutrient imbalance, or soil salinity, etc.) and in plant-microbe interactions $(4,5)$. Ethylene serves as a defense response stimulus inducing disease resistance or, conversely, may play a role in disease symptom development and in the breakdown of endogenous resistance $(1,5,32)$. Ethylene activates plant defense related processes involving phytoalexins, pathogenesis-related proteins, synthesis of $\beta$-1,3-glucanase, chitinase, phenylalanine ammonia-lyase, phenylpropanoids synthesis, hyp-rich glycoproteins, osmotin, and cell wall alteration by lignifications and flavonoids formation in plant tissues $(5,13)$. Ethylene signaling is required for resistance to certain pathogens of Arabidopsis, tobacco, and soybean mutants $(17,26,48)$. Conversely, ethylene increases severity of Verticillium wilt of tomato, and gray mold on rose and carnation flowers (5).

The relationship between rice blast and plant physiological responses related to anaerobic soil conditions is poorly researched. It is evident that disease defense responses are activated as the rice plant adapts to anaerobic conditions in the root zone. In the present study, we investigate the interrelationship between flood depth, oxygen, and partial resistance to rice blast. Utilizing the ethylene synthesis generator ethephon formulated as Prep (55.4\% ethephon), and the ethylene biosynthesis inhibitor aminoethoxyvinylglycine (AVG) formulated as Retain 15SP (15\% AVG), we also test the hypothesis that ethylene serves as a signaling molecule to induce plant resistance to the rice blast fungus.

\section{MATERIALS AND METHODS}

Rice cultivar characteristics. Cultivars were selected based on known resistance genes, differential responses to blast races, and observed differences in blast field resistance. M-201 is very susceptible to all test races in greenhouse evaluations and exhibits a very limited resistance when growing in a continuous deep (10 to $15 \mathrm{~cm}$ ) flood. Newbonnet, resistant to races IB-1 and IG-1 but susceptible to test races IB-49 and IC-17 in greenhouse evaluations, is very susceptible when grown upland or in shallow (1 to $2 \mathrm{~cm}$ ) flood conditions but exhibits moderate partial resistance when grown in continuous 10 - to $15-\mathrm{cm}$ flood. LaGrue is susceptible to all test races in greenhouse evaluations, with low partial resistance when grown upland and moderate to good partial resistance when grown under continuous 10- to $15-\mathrm{cm}$ flood. Mars is resistant to races IB-49 and IG-1 but susceptible to test races IB-1 and IC-17 in greenhouse evaluations, with good to excellent partial resistance when grown upland or in a shallow continuous flood. Cypress is resistant to races IB-1 and IG- 1 but susceptible to all other test races in greenhouse evaluations, with excellent field resistance when grown upland and blast resistant when grown in a shallow continuous flood. Saber contains major resistance gene $P i-b$, which confers resistance to test blast races in greenhouse and field tests. Katy and Drew contain the Pi-ta gene, which confers immunity to the test races in greenhouse and field tests. These cultivars very seldom develop blast symptoms except when growing in unusually moisture-stressed conditions and with excess urea nitrogen. Oryzica Llanos 5 contains several major resistance genes that confer immunity to known U.S. M. grisea races in greenhouse and field tests.

Plant culture. Pot experiments were conducted using Dewitt silt loam soil (fine, smectitic, thermic, Typic Albaqualfs) obtained from the Rice Research and Extension Center, Stuttgart, AR. Soil was sieved through $5-\mathrm{mm}$ mesh screens and placed into 12.5 by $15 \mathrm{~cm}$ (height by diameter) plastic pots to a depth of $10 \mathrm{~cm}$. Pots had four $0.5-\mathrm{cm}$ drainage holes. Each pot was planted with a
10 to 12 seed hill of four to six cultivars equidistantly spaced around the perimeter. To mimic paddy field conditions of nearly impermeable compacted soil (44), pots were temporarily flooded soon after seed germination to insure a slow percolation, allowed to dry, and lightly irrigated with deionized water as necessary for seedling development. During this process, the soil was puddled by hand in individual pots and/or additional soil was added to fill cracks developing after puddling. After watering and subsequent settling, final soil depth was typically $7.5 \mathrm{~cm}$. Plants were grown without use of herbicides or other chemicals to avoid contamination with unknown hormone interactions. Approximately 10 days after seeding, pots were hand-weeded and plants were thinned to six to eight healthy seedlings per hill.

Plants were grown for 4 weeks (V4) (12) under simulated upland conditions (19) by watering with deionized water at $100 \mathrm{ml}$ per day per pot the first week, $150 \mathrm{ml}$ per day per pot the second week, and $250 \mathrm{ml}$ per day per pot thereafter. Watering did not leave any surplus surface water after $30 \mathrm{~min}$ of application, and plants occasionally wilted temporarily. One day prior to applying treatments, the water was replaced with a $1 \%$ Peters solution containing 20:20:20 N:P:K. When experimental design required flood conditions, pots of upland plants were positioned inside larger pots ( 22.5 by $36 \mathrm{~cm}$, height by width), which were maintained near overflowing with deionized water to provide plants growing in a $15-\mathrm{cm}$ continuous flood. Greenhouse temperatures fluctuated between $27^{\circ} \mathrm{C}$ day and $24^{\circ} \mathrm{C}$ night; relative humidity (RH) was $70 \%$; and light photoperiod was $14 \mathrm{~h}$ day/10 h dark.

Flood depth. The flood depth experiment was designed from previous field experimental treatments that were shown to induce changes in cultivar blast susceptibility. Plants in deeper floods were less susceptible to blast than plants in shallow floods, which in turn were less susceptible than those growing upland. Three replications of individual pots containing V4 upland plants were placed on plastic-coated wire stands positioned at different depths inside a 378-liter capacity (60 by 50 by $100 \mathrm{~cm}$, height by width by length) plastic reservoir filled with soil to a depth of $10 \mathrm{~cm}$. Upland treatment conditions were simulated by placing only the bottom $2.5 \mathrm{~cm}$ of pots into the flooded reservoir. An intermediate flood depth treatment was established by positioning the floodsoil interface of previously upland plants at approximately $7.5 \mathrm{~cm}$ below the reservoir flood surface. A deep flood treatment was established by positioning the flood-soil interface of an additional set of previously upland plants at approximately $20 \mathrm{~cm}$ below the flood surface on the reservoir bottom. Deionized water was added to the reservoir to maintain the flood. Plants were maintained at their respective position within the reservoir until the V5 growth stage and then removed from the reservoir and immediately transferred into individual $22.5-\mathrm{cm}$-high pots filled with the appropriate quantity of deionized water required to maintain the respective upland and intermediate flood depth treatments. Pots from the $20-\mathrm{cm}$ treatment depth were placed in $22.5-\mathrm{cm}$ pots, which were filled with water. Plants were then inoculated with the mixed inoculum as described below then immediately returned to their original treatment location in the reservoir until lesions developed. Immediately prior to removing test plants for lesion evaluation, the DO, as the mean of two independent observations near the bottom of each pot, was determined with a portable DO meter (Cole-Parmer 53012; Cole-Palmer Instrument Company, Vernon Hills, IL).

Solution culture. Differential aeration of nutrient solution was used to determine the effect of low DO irrigation water associated with test cultivar changes in blast field resistance in field tests. Seed of cvs. M-201, LaGrue, Cypress, and Drew were planted in Redi-mix soil. At the first leaf (V1) growth stage, seedlings of each cultivar were wrapped in cotton and transferred into styrofoam strips floating in $38 \mathrm{~cm}$ (width) by $61 \mathrm{~cm}$ (length) by $33 \mathrm{~cm}$ (depth) ice chests containing 15 liters of nutrient solution. The strips provided aerial support for plant shoots, while roots floated 
freely in the nutrient solution. Each chest contained four styrofoam strips ( 5 by $25 \mathrm{~cm}$ ), each with four $3-\mathrm{cm}$ holes to provide one hole per cultivar, with two seedlings per hole. Nutrient solution composition was as described by Yoshida (53), initially formulated at 1/4 strength and changed weekly. The formulation was increased to $1 / 2$ strength after 3 weeks when plants had reached the V4 to V5 growth stage. Solution $\mathrm{pH}$ was maintained daily at $5.0 \pm 0.1$ by monitoring with a $\mathrm{pH}$ meter and adjusting with $1 \mathrm{~N}$ $\mathrm{NaOH}$ or $\mathrm{H}_{2} \mathrm{SO}_{4}$ as needed. Greenhouse conditions were as described previously.

Nitrogen treatments included 3 and $6 \mathrm{mM}$ rates of $\mathrm{N}$ as either nitrate or ammonia, while balancing overall chloride and sulfate anion levels. Aeration and nitrogen treatment combinations were randomly applied to individual chests 1 week after transfer to solution (14 days after planting). Aeration treatments were established by bubbling either $\mathrm{N}_{2}$ or $\mathrm{O}_{2}$ gas into the nutrient solution at a rate that was vigorous without affecting a "rolling boil." DO levels were measured using the previously described oxygen meter.

Plants from the liquid media experiment were inoculated with race IB-49 at the V5 plant growth stage. During inoculation, test plants were maintained in their respective nutrient-aeration conditions but without active gas movement when moved to the dew chamber. Active gas treatments were resumed following inoculation when plants were returned to their respective treatment solutions on the greenhouse bench. Seven days after inoculation, the numbers of each lesion type per inoculated leaf were recorded.

Ethylene regulator treatments. Because one response of rice to low DO is increased production of hormones, particularly ethylene, chemical regulators known to modify ethylene synthesis were applied to plants in both the presence and absence of a flood to provide a biological gauge for the role of root zone-produced hormones in flood-induced blast resistance. The ethylene generator was ethephon ([2-chloroethylphosphonic acid] formulated as Prep [55.4\% ethephon]). Ethephon was dissolved in deionized water and applied at $0.25,0.50$, or $0.75 \mathrm{mM}$ concentrations according to experimental design. The ethylene biosynthesis inhibitor was aminoethoxyvinylglycine hydrochloride ([S]-trans-2amino-4-[2-aminoethoxy]-3-butenoic acid hydrochloride), commonly called AVG and formulated as Retain 15SP (15\% AVG). AVG was applied at $0.31 \mathrm{mM}$ concentrations. Single application treatments were applied approximately 23 days after seeding to upland test plants, which were widely segregated on separate greenhouse benches to limit gaseous interaction between regulators. Foliar treatments were applied by atomizing $25 \mathrm{ml}$ of the designated ethylene regulator onto rice plants using an artist airbrush. Run off was allowed to collect on the soil surface. Drench treatments consisted of a total of $600 \mathrm{ml}$ of the designated ethylene regulator applied in four $150-\mathrm{ml}$ aliquots to facilitate soil absorption. A foliar-drench treatment consisted of applying the desired ethylene regulator to test plants by combining the foliar and the drench methods for a total of $625 \mathrm{ml}$ per application. Pots designated for the $15-\mathrm{cm}$ continuous flood were moved into $22-\mathrm{cm}$ pots immediately following treatment application. Nontreated control plants were established using distilled water applied in a like manner. Treatments were replicated three times.

Sequential hormone treatments were established according to experimental design using the same application methods. Where sequential treatments involved plants growing under continuous flood, the $12.5-\mathrm{cm}$ test pots were carefully removed from the flooded $22-\mathrm{cm}$ pots, placed on an incline in plastic trays and allowed to drain for $12 \mathrm{~h}$ prior to treatment application. Plants were returned to their original growing conditions $6 \mathrm{~h}$ following the additional foliar application and $12 \mathrm{~h}$ following the additional drench applications.

Pathogen isolates and inoculation. Pathogenicity tests were conducted using $M$. grisea races IB-1 strain ZN 15, IB-49 strain ZN 52, IC-17 strain ZN 1, and IG-1 strain ZN 39 (11). These races commonly occur in rice production fields of the southern
United States. Isolates were cultured using an alfalfa-rice bran medium (10 g of alfalfa pellets, $4 \mathrm{~g}$ of corn meal, $20 \mathrm{~g}$ of heatstabilized extruded rice bran, and $10 \mathrm{~g}$ of Difco agar in 1 liter of water) at $26^{\circ} \mathrm{C}$ for 7 to 10 days under $24 \mathrm{~h}$ light. Spore suspensions were prepared by dislodging spores from plates using distilled water containing $0.025 \%$ xanthan gum (Spectrum Quality Products, Gardena, CA). Inoculum was applied to plants with an artist airbrush until runoff occurred and, according to experimental design, consisted of either a single race at the rate of $4 \times$ $10^{5}$ spores per $\mathrm{ml}$ or a bulk of all races present at $2 \times 10^{5}$ spores per $\mathrm{ml}$. Immediately following inoculation, plants were moved into a dew chamber at $20 \pm 1{ }^{\circ} \mathrm{C}$ and $100 \% \mathrm{RH}$ in dark for $18 \mathrm{~h}$ and then returned to their original test positions.

Plants in ethylene regulator tests were inoculated with the multirace mixture 2 days following final regulator application. Original blocking to avoid interaction between gaseous treatments was maintained by placing inoculated plants into separate dew chambers according to regulator.

Treatment evaluation and rice blast index. Treatments were visually evaluated according to leaf lesion type using the standard $0=$ none to $9=$ maximum lesion development rating system (20) with the exceptions that a type 3 lesion is a small 1- to 2-mmdiameter oval to slightly elongated necrotic lesion with a distinct brown margin but without a gray discolored or sporulating center and that a type 4 is a typical reddish-brown blast lesions about $3 \mathrm{~mm}$ or longer with an ashy gray sporulating center and distinct margin. Resistance classification based upon the lesion types are as follows: 0 to $3=$ resistant, 4 to $6=$ susceptible, and 7 to $9=$ very susceptible plants.

The top two fully expanded inoculated leaves were selected from five plants of each replication and evaluated. Each leaf was assigned a visual rating score according to the most severe and predominating lesion type present although other lesions may have developed on the leaf. An average blast index (BI) was calculated with the individual leaf ratings using the following formula:

Blast index $(\mathrm{BI})=\frac{\text { Sum of numerical ratings from all leaves }}{(\text { number of leaves assesed }) \times(\text { maximum lesion rating }=9)} \times 100$

Statistical analysis. In this study, all experiments had a split plot treatment arrangement with the subplot being cultivar. The nutrient solution experimental design was a completely randomized factorial, combining two aeration treatments, two $\mathrm{N}$-form treatments, and two $\mathrm{N}$ rates into eight treatment combinations replicated twice with four observations per cultivar per replicate. In the other tests, main plot treatments were flood depth, aeration, regulator treatments, or a factorial arrangement of irrigation (flood and upland) and material applied (AVG, ethephon, or untreated control) according to respective experiments. With the exception of the nutrient culture experiment, all experiments were conducted with three to four replications and were repeated as a whole or partially more than two times. Test data were analyzed using the general linear models procedure in the SAS package. Flood depth and ethylene regulator least significant difference (LSD) values were calculated at $P=0.05$ for comparison of treatment means by Fisher's tests on Welch's analysis of variance. Treatment differences in the solution culture test were analyzed using Tukey's test.

\section{RESULTS}

Flood depth and DO. In the flood depth experiment, increasing the depth of treatment relative to flood surface reduced rice BI in all cultivars except M-201, which sustained substantial blast damage in all treatments (Table 1). Relative to the upland condition, the BI for Newbonnet was lowered by the 7.5-cm flood depth and lowered progressively more by the $20-\mathrm{cm}$ flood depth. The BI for LaGrue was lower at the $20-\mathrm{cm}$ flood depth only. The 
BIs for Mars and Cypress were lowered by both the 7.5- and $20-\mathrm{cm}$ flood depths. Cypress became virtually immune to rice blast at the 7.5- and 20-cm flood depths.

DO also decreased with increased depth of flood (Table 1). Relative to the flood surface, DO content near the root zone of test pots was lowered by the $7.5-$ and $20-\mathrm{cm}$ flood depths. Linear regression of cultivar BI with changes in DO resulted in the following relationships: M-201 $\left(Y=59.0+2.8 X ; R^{2}=0.23 ; P=\right.$ $0.19)$, Newbonnet $\left(Y=9.3+5.9 X ; R^{2}=0.65 ; P=0.008\right)$, LaGrue $\left(Y=8.5+4.5 X ; R^{2}=0.85 ; P=0.0002\right)$, Mars $(Y=2.8+4.1 X$; $\left.R^{2}=0.69 ; P=0.006\right)$, and Cypress $\left(Y=-9.7+3.9 X ; R^{2}=0.43\right.$; $P=0.05)$ where $Y=\mathrm{BI}$ and $X=\mathrm{DO}$.

The solution culture experiment tested effects of $\mathrm{N}$-form, $\mathrm{N}$ rate, and aeration on blast development in four rice cultivars differing in blast susceptibility. $\mathrm{N}$-form and $\mathrm{N}$-rate effects were not significant $(P>0.05)$. However, the aeration and $\mathrm{N}$-rate interaction was significant $(P=0.02)$. As $\mathrm{N}$-rate increased from 3 to $6 \mathrm{mM}$, lesions per leaf increased from 1.4 to 1.8 with anaerobic conditions and from 4.2 to 5.7 per leaf with aerated conditions. Aeration effect and the interaction between cultivars and aeration level were highly significant $(P=0.0001)$. DO in $\mathrm{O}_{2}$ treatments averaged $5.0 \mu \mathrm{liter}^{-1}$, while $\mathrm{N}_{2}$ treatments averaged $0.1 \mu \mathrm{l} \mathrm{liter}{ }^{-1}$ of DO. Total numbers of blast lesions on inoculated leaves of plants growing in the 5.0- $\mu$ l liter ${ }^{-1}$ DO solution were 3.4 and 3.2 times greater in cvs. M-201 $(P=0.001)$ and LaGrue $(P=0.01)$, respectively, than on leaves of plants growing in the $0.1-\mu l$ liter $^{-1}$ DO solution. Lesion numbers on Cypress and Drew were unchanged. Cultivar susceptibility ranking was similar to that expressed under field conditions and was not affected by aeration.

TABLE 1. Effect of flood depth on dissolved oxygen and rice blast

\begin{tabular}{lcccccc}
\hline Flood & Dissolved & \multicolumn{5}{c}{ Blast index $^{\mathrm{z}}$} \\
\cline { 3 - 7 } $\begin{array}{l}\text { treatment } \\
\text { oxygen }\end{array}$ & $\begin{array}{c}\text { depth } \\
$\cline { 3 - 7 } \text {$\left.liter }\end{array}{ }^{-1}\right)$ & M-201 & Newbonnet & LaGrue & Mars & Cypress \\
\hline Upland & $6.73 \mathrm{a}$ & $83.0 \mathrm{a}$ & $54.8 \mathrm{a}$ & $39.6 \mathrm{a}$ & $34.5 \mathrm{a}$ & $25.5 \mathrm{a}$ \\
$7.5 \mathrm{~cm}$ & $6.21 \mathrm{~b}$ & $70.4 \mathrm{a}$ & $40.0 \mathrm{~b}$ & $35.5 \mathrm{a}$ & $23.3 \mathrm{~b}$ & $4.0 \mathrm{~b}$ \\
$20.0 \mathrm{~cm}$ & $2.57 \mathrm{c}$ & $66.7 \mathrm{a}$ & $24.4 \mathrm{c}$ & $20.0 \mathrm{~b}$ & $14.1 \mathrm{~b}$ & $1.8 \mathrm{~b}$ \\
\hline
\end{tabular}

${ }^{\mathrm{z}}$ Means within a column followed by the same letter do not differ significantly at $P=0.05$ according to Fisher's least significant difference test.

TABLE 2. Blast indices of rice cultivars following a single foliar-drench treatment with ethephon applied 26 days after sowing

\begin{tabular}{|c|c|c|c|c|c|c|}
\hline \multirow{2}{*}{$\begin{array}{l}\text { Plant } \\
\text { culture }\end{array}$} & \multirow[b]{2}{*}{ Treatment } & \multicolumn{5}{|c|}{ Blast index ${ }^{z}$} \\
\hline & & M-201 & Newbonnet & LaGrue & Mars & Cypress \\
\hline Upland & Nontreated & $94.4 \mathrm{a}$ & 78.9 a & $91.8 \mathrm{a}$ & $83.7 \mathrm{a}$ & $70.7 \mathrm{a}$ \\
\hline Flood & Nontreated & $81.6 \mathrm{bc}$ & $48.3 \mathrm{bc}$ & $62.6 \mathrm{c}$ & $52.6 \mathrm{c}$ & $40.8 \mathrm{~b}$ \\
\hline Upland & $\begin{array}{l}\text { Ethephon } \\
(0.25 \mathrm{mM})\end{array}$ & $78.7 \mathrm{c}$ & $42.2 \mathrm{c}$ & $57.8 \mathrm{c}$ & $61.9 \mathrm{bc}$ & $35.6 \mathrm{~b}$ \\
\hline Upland & $\begin{array}{l}\text { Ethephon } \\
(0.50 \mathrm{mM})\end{array}$ & $82.6 \mathrm{bc}$ & $51.9 \mathrm{~b}$ & $72.9 \mathrm{~b}$ & $66.7 \mathrm{~b}$ & $43.0 \mathrm{~b}$ \\
\hline Upland & $\begin{array}{l}\text { Ethephon } \\
(1.00 \mathrm{mM})\end{array}$ & $85.6 \mathrm{~b}$ & $50.6 \mathrm{~b}$ & $73.8 \mathrm{~b}$ & $65.2 \mathrm{bc}$ & $45.5 \mathrm{~b}$ \\
\hline
\end{tabular}

${ }^{\mathrm{z}}$ Means within a column followed by the same letter do not differ significantly at $P=0.05$ according to Fisher's least significant difference test.
Ethylene regulator treatments. The predominant treatment response to either ethephon or AVG was a decrease or increase in the BI relative to analogous nontreated test plants. The only other observable response to treatment was an occasional temporary chlorosis in newly emerging leaves of some plants treated with AVG.

The BIs of nontreated upland plants were compared with those of nontreated flooded plants and those of upland plants treated with a single foliar-drench application of ethephon at $0.25,0.50$, or $1.00 \mathrm{mM}$ (Table 2). The BIs of nontreated flood plants were lower than the BIs of nontreated upland plants of test cultivars. All ethephon treatments lowered the BI of cultivars growing upland. The BIs of the nontreated flood treatment and $0.25 \mathrm{mM}$ ethephon upland treatment were not different for any cultivar $(P=$ $0.05)$. The BIs of plants treated with $0.50 \mathrm{mM}$ ethephon were not different from those treated with $0.25 \mathrm{mM}$ ethephon, except for cvs. Newbonnet and LaGrue. The BIs of plants treated with $1.00 \mathrm{mM}$ ethephon were not different from those treated with $0.50 \mathrm{mM}$ ethephon but were significantly greater than the BIs of cvs. M-201, Newbonnet, and LaGrue treated with $0.25 \mathrm{mM}$ ethephon.

The BIs of upland plants treated with one, two, or three foliardrench applications of $0.50 \mathrm{mM}$ ethephon were compared with that of nontreated upland and nontreated flood plants (Table 3). Relative to nontreated upland plants, all ethephon application regimes decreased the BI for all cultivars. Relative to nontreated flood plants, all ethephon applications decreased the BI for M201, LaGrue, Mars, and Cypress. Although data from two and three applications suggest a downward trend in the BI for all cultivars, only the BI for Newbonnet with three ethephon applications differed from that of the single application treatment.

Experiments were conducted to compare cultivar response, relative to nontreated plants, to a single drench or foliar application of $0.25 \mathrm{mM}$ ethephon or $0.31 \mathrm{mM}$ AVG when growing upland or flood (Table 4). The BIs of ethephon-treated upland plants decreased for all cultivars except for very susceptible M-201. With drench application, the BIs of ethephon-treated flood plants decreased for all cultivars except LaGrue. The BIs of ethephontreated flood plants did not change with foliar application. The BIs of AVG-treated upland plants were unchanged. Within drench AVG-treated flood plants, the BI of Cypress increased, whereas the BIs of the other cultivars were unchanged. Within foliar AVGtreated flood plants, the BI of M-201 remained unchanged, whereas the BIs of the other cultivars increased.

In similar fashion, experiments were conducted to compare test cultivar response, relative to nontreated plants, following two drench, two foliar, or two foliar-drench sequential applications of $0.25 \mathrm{mM}$ ethephon or $0.31 \mathrm{mM}$ AVG while growing upland or flood (Table 5). With exception of M-201 with foliar application, the BIs of ethephon-treated upland plants decreased for all cultivars regardless of application method. The BIs of ethephontreated flood plants decreased for all cultivars with drench application, were unchanged with foliar application, and decreased for cvs. M-201, Newbonnet, and LaGrue with drench-foliar application but not for Cypress. As before, the BIs of AVG-treated upland plants were unchanged. With AVG-treated flood plants, the

TABLE 3. Blast indices of rice cultivars following sequential foliar-drench treatments with ethephon

\begin{tabular}{|c|c|c|c|c|c|c|}
\hline \multirow[b]{2}{*}{ Plant culture } & \multirow[b]{2}{*}{ Treatment } & \multicolumn{5}{|c|}{ Blast index ${ }^{\mathrm{y}}$} \\
\hline & & M-201 & Newbonnet & LaGrue & Mars & Cypress \\
\hline Upland & Nontreated & 90.6 a & $64.8 \mathrm{a}$ & $88.5 \mathrm{a}$ & $84.4 \mathrm{a}$ & $60.4 \mathrm{a}$ \\
\hline Flood & Nontreated & $81.9 \mathrm{a}$ & $42.2 \mathrm{~b}$ & $57.8 \mathrm{~b}$ & $65.6 \mathrm{~b}$ & $33.0 \mathrm{~b}$ \\
\hline Upland & Ethephon $(0.50 \mathrm{mM}) 29 \mathrm{DAS}^{\mathrm{z}}$ & $72.9 \mathrm{~b}$ & $34.5 \mathrm{~b}$ & $40.7 \mathrm{c}$ & $47.8 \mathrm{c}$ & $25.6 \mathrm{c}$ \\
\hline Upland & Ethephon $(0.50 \mathrm{mM}) 26$ and 29 DAS & $70.4 \mathrm{~b}$ & $32.5 \mathrm{bc}$ & $39.6 \mathrm{c}$ & $51.1 \mathrm{c}$ & $24.5 \mathrm{c}$ \\
\hline Upland & Ethephon $(0.50 \mathrm{mM}) 23,26$, and 29 DAS & $68.3 \mathrm{~b}$ & $22.2 \mathrm{c}$ & $37.4 \mathrm{c}$ & $43.3 \mathrm{c}$ & $18.9 \mathrm{c}$ \\
\hline
\end{tabular}

${ }^{y}$ Means within a column followed by the same letter do not differ significantly at $P=0.05$ according to Fisher's least significant difference test.

${ }^{\mathrm{z}}$ Days after seeding. 
BIs of all cultivars were increased with the drench application, the BI of only M-201 increased with foliar application, and the BIs of cvs. Newbonnet, LaGrue, and Cypress were increased with the drench-foliar applications.

The BIs of resistant cvs. Drew, Katy, Oryzica Llanos 5, and Saber were compared with those of susceptible cvs. Cypress and M201 following two foliar-drench applications of $0.25 \mathrm{mM}$ ethephon or $0.31 \mathrm{mM}$ AVG (Table 6). Differences between the BIs of nontreated upland and flood plants were observed with cvs. M201, Cypress, and Saber but not with cvs. Drew, Katy, and Oryzica Llanos 5. Relative to nontreated upland plants, BIs of nontreated and ethephon-treated flood plants decreased for cvs. M-201, Cypress, and Saber only. BIs of AVG-treated flood plants increased for all cultivars.

\section{DISCUSSION}

Rice researchers and farmers have long observed the correlation between anaerobic soil conditions and increased blast resistance without benefit of an adequate explanation. Hypotheses to explain responsible mechanisms have remained limited by the lack of definition of an independent variable. These experiments reproduce the effect of anaerobic conditions on expression of partial blast resistance, delineate aeration as an independent variable associated with the phenomenon, and demonstrate a role for ethylene in expression of rice blast resistance.

Reproducing grower and research field test observations, known flood responsive rice cvs. Newbonnet, LaGrue, Mars, and Cypress became increasingly resistant as depth of flood increased to 7.5 and $20 \mathrm{~cm}$ in the flood depth experiment. The test defined DO as the primary variable associated with these flood depth-related changes in blast resistance. The solution culture experiment further confirms the association between low DO and increased blast resistance as observed with the flood depth test. More importantly, the solution culture experiment defined aeration as a dominant variable influencing resistance to rice blast. Unlike a soil medium, the solution culture system maintains constant redox potentials with changes in aeration because the low available carbon source limits microbial growth. The influence of $\mathrm{N}$-form and
$\mathrm{N}$-rate was separated from that of DO relative to changes in blast resistance in that test. In nontreated comparisons, the BIs of cvs. Newbonnet, LaGrue, and Cypress growing in the $20-\mathrm{cm}$ flood were, with one noted exception (LaGrue), reduced from their BIs when growing upland. When considered altogether, the data establish flood dependent DO as a mediator of partial resistance to blast.

Although we did not present ethylene concentration data from test plants, increased ethylene synthesis is firmly linked with anaerobic oxygen depletion $(3,10,35,42,51)$. The role of ethylene as a stimulus that activates plant defense mechanisms and alters disease resistance is well published $(1,4,5,17,26,32,48)$. Data presented here demonstrating changes in the BIs of plants treated with ethephon, which releases ethylene, and with AVG, an ethylene biosynthesis inhibitor, clearly identifies a primary role for ethylene in resistance expression to $M$. grisea. This role is most evident in upland plants. In six evaluations of flood responsive cvs. Newbonnet, LaGrue, and Cypress, the BIs of $0.25 \mathrm{mM}$ ethephon-treated upland plants decreased, with one exception of a single foliar application to Cypress, following one or two treatments regardless of application being drench, foliar, or foliardrench (Tables 2, 4, and 5). Although unresponsive to foliar application, the BIs of the ethephon-treated flooded plants of these

TABLE 6. Blast indices of rice cultivars following sequential foliar-drench treatments with ethephon or AVG applied 24 and 28 days after sowing

\begin{tabular}{lcrrrrrr}
\hline & & \multicolumn{6}{c}{ Blast index $^{\mathrm{z}}$} \\
\cline { 3 - 8 } $\begin{array}{l}\text { Plant } \\
\text { culture }\end{array}$ & Treatment & Drew & Katy & Llanos-5 & Saber & Cypress & M-201 \\
\hline Flood & AVG & & & & & & \\
& $(0.31 \mathrm{mM})$ & $37.4 \mathrm{a}$ & $29.6 \mathrm{a}$ & $28.5 \mathrm{a}$ & $26.7 \mathrm{a}$ & $48.5 \mathrm{a}$ & $61.1 \mathrm{a}$ \\
Upland & Nontreated & $4.4 \mathrm{~b}$ & $7.4 \mathrm{~b}$ & $0.7 \mathrm{~b}$ & $5.9 \mathrm{~b}$ & $26.3 \mathrm{~b}$ & $51.1 \mathrm{~b}$ \\
$\begin{array}{l}\text { Flood } \\
\text { Flood }\end{array}$ & $\begin{array}{c}\text { Nontreated } \\
\text { Ethephon } \\
\end{array}$ & $1.8 \mathrm{~b}$ & $3.3 \mathrm{~b}$ & $0.4 \mathrm{~b}$ & $1.1 \mathrm{c}$ & $4.8 \mathrm{c}$ & $23.3 \mathrm{c}$ \\
& $(0.25 \mathrm{mM})$ & $1.5 \mathrm{~b}$ & $2.9 \mathrm{~b}$ & $0.7 \mathrm{~b}$ & $1.1 \mathrm{c}$ & $3.3 \mathrm{c}$ & $25.9 \mathrm{c}$ \\
\hline
\end{tabular}

${ }^{\mathrm{z}}$ Means within a column followed by the same letter do not differ significantly at $P=0.05$ according to Fisher's least significant difference test.

TABLE 4. Blast indices of rice cultivars following a drench or foliar treatment with ethephon or AVG applied 23 days after sowing

\begin{tabular}{|c|c|c|c|c|c|c|c|c|c|}
\hline \multirow[b]{3}{*}{ Plant culture } & \multirow[b]{3}{*}{ Treatment } & \multicolumn{8}{|c|}{ Blast index ${ }^{z}$} \\
\hline & & \multicolumn{4}{|c|}{ Drench } & \multicolumn{4}{|c|}{ Foliar } \\
\hline & & M-201 & Newbonnet & LaGrue & Cypress & M-201 & Newbonnet & LaGrue & Cypress \\
\hline Upland & $\operatorname{AVG}(0.31 \mathrm{mM})$ & $88.5 \mathrm{a}$ & $82.9 \mathrm{a}$ & $76.6 \mathrm{a}$ & $61.9 \mathrm{a}$ & $92.2 \mathrm{a}$ & $70.7 \mathrm{a}$ & $70.4 \mathrm{a}$ & $50.7 \mathrm{ab}$ \\
\hline Upland & Nontreated & $88.5 \mathrm{a}$ & $69.6 \mathrm{ab}$ & $67.0 \mathrm{ab}$ & $62.6 \mathrm{a}$ & $86.3 \mathrm{a}$ & $74.1 \mathrm{a}$ & $73.0 \mathrm{a}$ & $52.9 \mathrm{a}$ \\
\hline Upland & Ethephon $(0.25 \mathrm{mM})$ & $80.4 \mathrm{a}$ & $48.5 \mathrm{de}$ & $50.7 \mathrm{c}$ & $35.6 \mathrm{~b}$ & $80.0 \mathrm{ab}$ & $46.3 \mathrm{~b}$ & $47.8 \mathrm{c}$ & $36.6 \mathrm{bc}$ \\
\hline Flood & $\operatorname{AVG}(0.31 \mathrm{mM})$ & $92.9 \mathrm{a}$ & $66.3 \mathrm{bc}$ & $61.5 \mathrm{bc}$ & $64.1 \mathrm{a}$ & $82.2 \mathrm{ab}$ & $61.9 \mathrm{a}$ & $66.7 \mathrm{ab}$ & $45.5 \mathrm{ab}$ \\
\hline Flood & Nontreated & $83.3 \mathrm{a}$ & $51.5 \mathrm{~cd}$ & $57.7 \mathrm{bc}$ & $45.9 \mathrm{~b}$ & $75.6 \mathrm{ab}$ & $40.7 \mathrm{~b}$ & $44.8 \mathrm{c}$ & $26.3 \mathrm{c}$ \\
\hline Flood & Ethephon $(0.25 \mathrm{mM})$ & $60.7 \mathrm{~b}$ & $33.7 \mathrm{e}$ & $33.7 \mathrm{c}$ & $19.3 \mathrm{c}$ & $67.0 \mathrm{~b}$ & $38.2 \mathrm{~b}$ & $49.3 \mathrm{bc}$ & $28.5 \mathrm{c}$ \\
\hline
\end{tabular}

${ }^{\mathrm{z}}$ Means within a column followed by the same letter do not differ significantly at $P=0.05$ according to Fisher's least significant difference test.

TABLE 5. Blast indices of rice cultivars following two sequential drench, foliar or foliar-drench treatments with ethephon or AVG applied 23 and 38 days after sowing

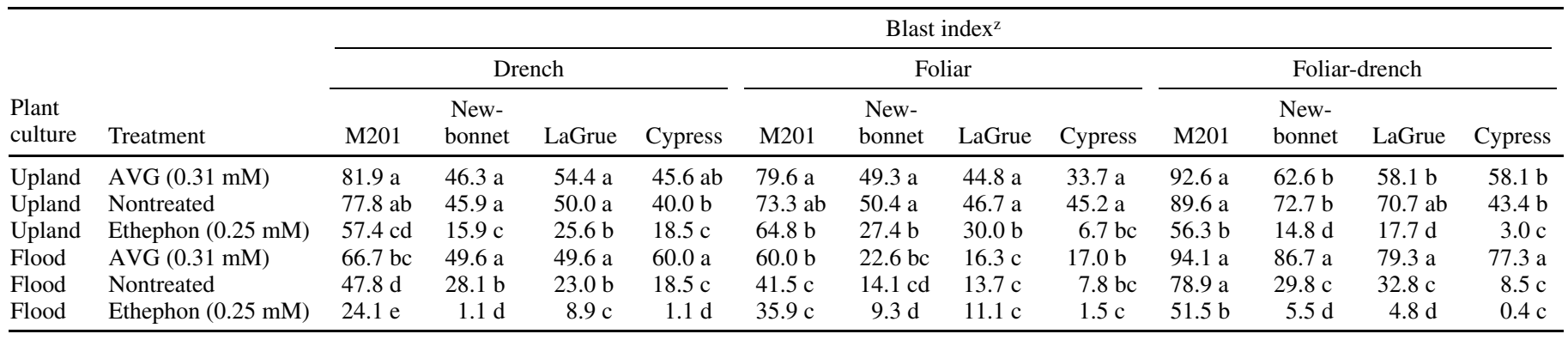

${ }^{\mathrm{z}}$ Means within a column followed by the same letter do not differ significantly at $P=0.05$ according to Fisher's least significant difference test. 
cultivars were decreased, with noted exceptions in Cypress and LaGrue, by drench and foliar-drench applications (Tables 4 and 5).

The blast susceptibility ranking of M-201, Newbonnet, LaGrue, and Cypress cultivars treated with ethephon is similar to that observed in previous flood-induced blast resistance data $(27,30)$. The response for very susceptible cv. M-201 is erratic but appears to follow trends exhibited by the more resistant cultivars. Newbonnet, LaGrue, and Cypress were susceptible if grown upland or with AVG-flood treatments but became moderately resistant or resistant with ethephon-upland or ethephon-flood treatment combinations. The relationship between inherent susceptibility and magnitude of response to flood and ethylene treatments requires additional investigation.

Conversely, blocking ethylene accumulation in flooded susceptible and resistant plants by AVG treatment restores blast susceptibility and further indicates that ethylene mediates signals upstream of the R-gene resistance expression. In addition to the observed disease response, the occasional chlorosis associated with AVG treatment likely results from an unidentified association with a number of other plant response sequences where ethylene is a critical component. However, the reduced photosynthesis may have weakened defenses against $M$. grisea.

The lack of increased response with an increasing rate of ethephon is puzzling but not unique. For example, pathogenesisrelated gene expression in rice was found to be tightly regulated in a dose-dependent manner at very low ethylene concentrations but was significantly decreased with higher concentrations (2). These observations could also explain why the BI was generally unchanged by two or three $0.50 \mathrm{mM}$ ethephon foliar-drench applications made within a 6-day interval compared with that of one application (Table 3). These data, in conjunction with published research on ethylene's accumulative properties within flooded rice $(10,35,42,51)$, may explain our long-term field observation that blast field resistance increases in cvs. Newbonnet, LaGrue, and Mars with depth and duration of continuous flood (unpublished data).

Data presented here support the hypothesis that changes in rice blast observed with partial blast-resistant cultivars during anaerobic conditions are in reality the plant response to changes in soil aeration, which mediates production of phytohormones, primarily ethylene, with a subsequent modification in expression of blast resistance.

\section{ACKNOWLEDGMENTS}

This research was funded in part by grants from the Arkansas Rice Research and Promotion Board. We thank M. Emerson and H. Mullins for technical support and our co-workers and the reviewers for valued assistance with the manuscript.

\section{LITERATURE CITED}

1. Abeles, G. B., Morgan, P. W., and Saltveit, M. E. 1992. Ethylene in Plant Biology. Academic Press, San Diego, CA.

2. Agrawal, G. K., Rakwal, R., and Jwa, N. 2001. Differential induction of three pathogenesis-related genes, PR10, PR1b, and PR5 by the ethylene generator ethephon under light and dark in rice (Oryza sativa L.) seedlings. J. Plant Physiol. 158:133-137.

3. Banga, M., Blom, C. W. P. M., and Voesenek, L. A. C. J. 1996. Sensitivity to ethylene: The key factor in submergence-induced shoot elongation of Rumex. Plant Cell Environ. 19:1423-1430.

4. Bleecker, A. B., and Kende, H. 2000. Ethylene: A gaseous signal molecule in plants. Annu. Rev. Cell Dev. Biol. 16:13-18.

5. Boller, T. 1991. Ethylene in pathogenesis and disease resistance. Pages 293-314 in: The Plant Hormone Ethylene. A. K. Matoo and J. C. Suttle, eds. CRC Press, Boca Raton, FL.

6. Bonman, J. M., Estrada, B. A., and Bandong, J. M. 1989. Leaf and neck blast resistance in tropical lowland rice cultivars. Plant Dis. 73:388390 .

7. Bonman, J. M., Estrada, B. A., Kim, C. K., Ra, D. S., and Lee, E. J. 1991. Assessment of blast disease and yield loss in susceptible and partially resistant rice cultivars in two irrigated lowland environments. Plant Dis. 75:462-466

8. Bonman, J. M., Sanchez, L. M., and Mackill, A. O. 1988. Effects of water deficit on rice blast. II. Disease development in the field. J. Plant Prot. Trop. 5:67-73.

9. Chapman, A. L., and Mikkelsen, D. S. 1963. Effect of dissolved oxygen supply on seedling establishment of water-sown rice. Crop Sci. 3:392397.

10. Cohen, E., and Kende, H. 1987. In vivo 1-aminocyclopropane-1-carboxylate synthase activity in internodes of deepwater rice. 1. Enhancement by submergence and low oxygen levels. Plant Physiol. 84:282-286.

11. Correll, J. C., Harp, T. J., Guerber, J. C., Zeigler, R. S., Liu, B., Cartwright, R. D., and Lee, F. N. 2000. Characterization of Pyricularia grisea from rice in the United States using independent genetic and molecular markers. Phytopathology 90:1396-1404.

12. Counce, P. A., Keisling, T. C., and Mitchell, A. J. 2000. A uniform objective and adoptive system for expressing rice development. Crop Sci. 40:436-443.

13. Deikman, J. 1997. Molecular mechanisms of ethylene regulation of gene transcription. Physiol. Plant 100:561-566.

14. El Refaei, M. I. 1977. Epidemiology of rice blast disease in the tropics with special reference to the leaf wetness in relation to disease development. Ph.D. diss. Indian Agricultural Research Institute, New Delhi.

15. Gill, M. A., and Bonman, J. M. 1988. Effects of water deficit on rice blast. I. Influence of water deficit on components of resistance. J. Plant Prot. Trop. 5:61-66.

16. Greenwood, D. J. 1961. The effect of oxygen concentration on the decomposition of organic material in soil. Plant Soil 14:360-366.

17. Hoffman, T., Schmidt, S. J., Zheng, X., and Bent, A. F. 1999. Isolation of ethylene insensitive soybean mutants that are altered in pathogen-susceptibility and gene for gene disease resistance. Plant Physiol. 119:935-949.

18. Imbe, T., Tsunematsu, H., Kato, H., and Khush, G. S. 2000. Genetic analysis of blast resistance in IR varieties and resistant breeding strategy. Pages 1-8 in: Advances in Rice Blast Research. D. Tharreau, M. H. Lebrun, N. J. Talbot, and J. L. Notteghem, eds. Kluwer Academic Publishers, Dordrecht, the Netherlands.

19. International Rice Research Institute (IRRI). 1999. Program Report for 1999. IRRI, Los Banos, Philippines.

20. International Rice Research Institute (IRRI). 2002. Reference GuideStandard Evaluation System for Rice (SES). IRRI, Los Banos, Philippines.

21. Kahn, R. P., and Libby, J. L. 1958. The effect of environmental factors and plant age on the infection of rice by the blast fungus Pyricularia oryzae. Phytopathology 48:25-30.

22. Kende, H., Van der Knapp, E., and Cho, H. T. 1998. Deepwater rice: A model plant to study stem elongation. Plant Physiol. 118:1105-1110.

23. Kim, C. H., Rush, M. C., and MacKenzie, D. R. 1984. Effect of water management on the epidemic development of rice blast. Pages 274-276 in: 76th Annual Progress Report-Louisiana. Agricultural Experiment Station, Baton Rouge, LA.

24. Kim, C. H., Rush, M. C., and MacKenzie, D. R. 1985. Epidemiology of rice blast under different water management practices. Pages 263-264 in: 77th Annual Progress Report-Louisiana. Agricultural Experiment Station, Baton Rouge, LA.

25. Kim, C. H., Rush, M. C., and MacKenzie, D. R. 1986. Flood-mediated resistance to the rice blast disease. Pages 151-160 in: The Wetlands and Rice in Sub-Saharan Africa. A. S. R. Juo and J. A. Lowe, eds. International Institute of Tropical Agriculture, Ibadan.

26. Knoester, M., van Loon, L. C., van den Heuvel, J., Hennig, J., Bol, J. F., and Linthorst, H. J. M. 1998. Ethylene-insensitive tobacco lacks non-host resistance against soil-borne fungi. Proc. Natl. Acad. Sci. USA 95:19331937.

27. Lai, X. H., Marchetti, M. A., and Petersen, H. D. 1999. Comparative slow-blasting in rice grown under upland and flooded blast nursery culture. Plant Dis. 83:681-684.

28. Lee, F. N. 1994. Rice breeding programs, blast epidemics and blast management in the United States. Pages 489-500 in: Rice Blast Disease. R. S. Zeigler, S. A. Leong, and P. S. Teng, eds. CAB International, Wallingford, UK.

29. Lee, F. N. 1999. Germplasm evaluation and enhancement for disease resistance. Pages 70-73 in: Proc. Int. Symp. Rice Germplasm Evaluation and Enhancement. J. N. Rutger, J. F. Robinson, and R. H. Dilday, eds. Arkansas Agricultural Experiment Station, University of Arkansas, Fayetteville, AR

30. Lee, F. N., and McMinn, T. A. 1996. Preliminary report on continuous flood depth influence on blast (Pyricularia grisea) in rice. Pages 139-144 in: Arkansas rice research studies 1995. R. J. Norman and B. R. Wells, eds. Ark. Agric. Exp. Stn. Res. Ser. 453.

31. Lorbiecke, R., and Sauter, M. 1999. Adventitious root growth and cellcycle induction in deepwater rice. Plant Physiol. 119:21-30. 
32. Lund, S. T., Stall, R. E., and Klee, H. J. 1998. Ethylene regulates the susceptible response to pathogen infection in tomato. Plant Cell 10:371-382.

33. Marchetti, M. A. 1994. Race-specific and rate-reducing resistance to rice blast in U.S. rice cultivars. Pages 231-244 in: Rice Blast Disease. R. S. Ziegler, S. A. Leong, and P. S. Teng, eds. CAB International, Wallingford, UK.

34. Matoo, A. K., and Suttle, J. C. 1991. The Plant Hormone Ethylene. CRC Press, Boca Raton, FL.

35. Métraux, J. P., and Kende, H. 1983. The role of ethylene in the growth response of submerged deepwater rice. Plant Physiol. 72:441-446.

36. Osuna-Canizalez, F. J., De Datta, S. K., and Bonman, J. M. 1991. Nitrogen form and silicon nutrition effects on resistance to blast disease of rice. Plant Soil 135:223-231.

37. Ou, S. H. 1985. Rice Diseases. 2nd ed. Commonw. Mycol. Inst., Kew, England.

38. Patrick, W. H., and Sturgis, M. B. 1955. Concentration and movement of oxygen as related to absorption of ammonium and nitrate nitrogen by rice. Soil Sci. Soc. Am. Proc. 19:59-62.

39. Perata, P., and Alpi, A. 1993. Plant responses to anaerobiosis. Plant Sci. 93:1-17.

40. Petruzzelli, L., Coraggio, I., and Leubner-Metzger, G. 2000. Ethylene promotes ethylene biosynthesis during pea seed germination by positive feedback regulation of 1-aminocyclo-propane-1-carboxilic acid oxidase. Planta 211:144-149.

41. Ponnamperuma, F. N. 1972. The chemistry of submerged soils. Adv. Agron. 24:29-96.

42. Raskin, I., and Kende, H. 1984. Regulation of growth in stem sections of deepwater rice. Planta 160:66-72.

43. Roumen, E. C. 1994. A strategy for accumulating genes for partial resistance to blast disease in rice within a conventional breeding program. Pages 245-266 in: Rice Blast Disease. R. S. Zeigler, S. A. Leong, and P. $\mathrm{S}$. Teng, eds. CAB International, Wallingford, UK.
44. Rowell, D. L. 1988. Flooded and poorly drained soils. Pages 899-926 in: Russell's Soil Conditions and Plant Growth. A. Wild, ed. Longman Scientific \& Technical, Essex, England.

45. Sah, D. N., and Bonman, J. M. 1992. Effects of seedbed management on blast development in susceptible and partially resistant rice cultivars. J. Phytopathol. 136:73-81.

46. Scott, A. D., and Evans, D. D. 1955. Dissolved oxygen in saturated soil. Soil Sci. Soc. Am. Proc. 19:7-12.

47. Suzuki, H. 1975. Meteorological factors in the epidemiology of rice blast (Pyricularia oryzae). Annu. Rev. Phytopathol. 13:239-256.

48. Thomma, B. P. H. J., Eggermont, K., Tierens, K. F. M. J., and Broekaert, W. F. 1999. Requirement of functional ethylene-insensitive 2 gene for efficient resistance of Arabidopsis to infection by Botrytis cinerea. Plant Physiol. 121:1093-1101.

49. Turner, F. T., Chen, C., and McCauley, G. N. 1981. Morphological development of rice seedlings in water at controlled oxygen levels. Agron. J. 73:566-570.

50. Turner, F. T., and Patrick, W. H., Jr. 1968. Chemical changes in waterlogged soils as a result of oxygen depletion. 9th Int. Congr. Soil Sci. 4:5365 .

51. Van Der Straeten, D., Zhou, Z., Prinsen, E., Van Onckelen, H. A., and Van Montagu, M. C. 2001. A comparative molecular-physiological study of submergence response in lowland and deepwater rice. Plant Physiol. 125:955-968.

52. Yamaguchi, M., Saitoh, H., and Higashi, T. 2000. Effect of varietal field resistance for control of rice blast. Pages 196-202 in: Advances in Rice Blast Research. D. Tharreau, M. H. Lebrun, N. J. Talbot, and J. L. Notteghem, eds. Kluwer Academic Publishers, Dordrecht, the Netherlands.

53. Yoshida, S. 1976. Routine procedure for growing rice plants in culture solution. Pages 61-66 in: Laboratory Manual for Physiological Studies of Rice. S. Yoshida, D. A. Forno, J. H. Cook, and K. A. Gomez, eds. IRRI, Manilia, Philippines. 